\title{
Implications of volcanic erratics in Quaternary deposits of North Greenland.
}

\author{
SVEND FUNDER AND OLE LARSEN
}

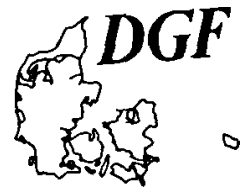

Funder, S. and Larsen, O.: Implications of volcanic erratics in Quaternary deposits of North Greenland. Bull. geol. Soc. Denmark, vol. 31, pp. 57-61. Copenhagen, November 15th, 1982. https://doi.org/10.37570/bgsd-1982-31-05

Erratic boulders, petrographically similar to the volcanics exposed around Kap Washington, are found on islands and along the coast much further to the east. Isotopic measurements on two such boulders show that these volcanic rocks are of the same age as the Kap Washington volcanics. The regional distribution of the erratics supports glacial morphological evidence for a major Weichselian ice flow moving eastwards along the coast of North Greenland.

S. Funder and O. Larsen, Geologisk Centralinstitut, Østervoldgade 10, DK-1350, June 17th, København $K$.

Volcanic erratic boulders in

\section{Quaternary deposits}

Erratics petrographically similar to the volcanics of the Kap Washington Group occur abundantly on two small islands, Kaffeklubben $\varnothing$ and Oodaaq $\varnothing$, approximately 80 kilometers east of Kap Washington (fig. 1). Their occurrence on these islands is surprising in view of the distance from their suspected source and the fact that volcanic erratics are extremely rare on the coastal plain bordering the north coast of Greenland. In order to confirm isotopically the origin of these erractics as part of the Kap Washington volcanics the $\mathrm{Sr}$-isotopic composition of two samples of such erratics were measured and compared with isotopic data obtained from the volcanics themselves (Larsen, 1982).

One sample was selected among the volcanic boulders from Oodaaq $\varnothing$, approximately $80 \mathrm{ki}$ lometers east of Kap Washington.
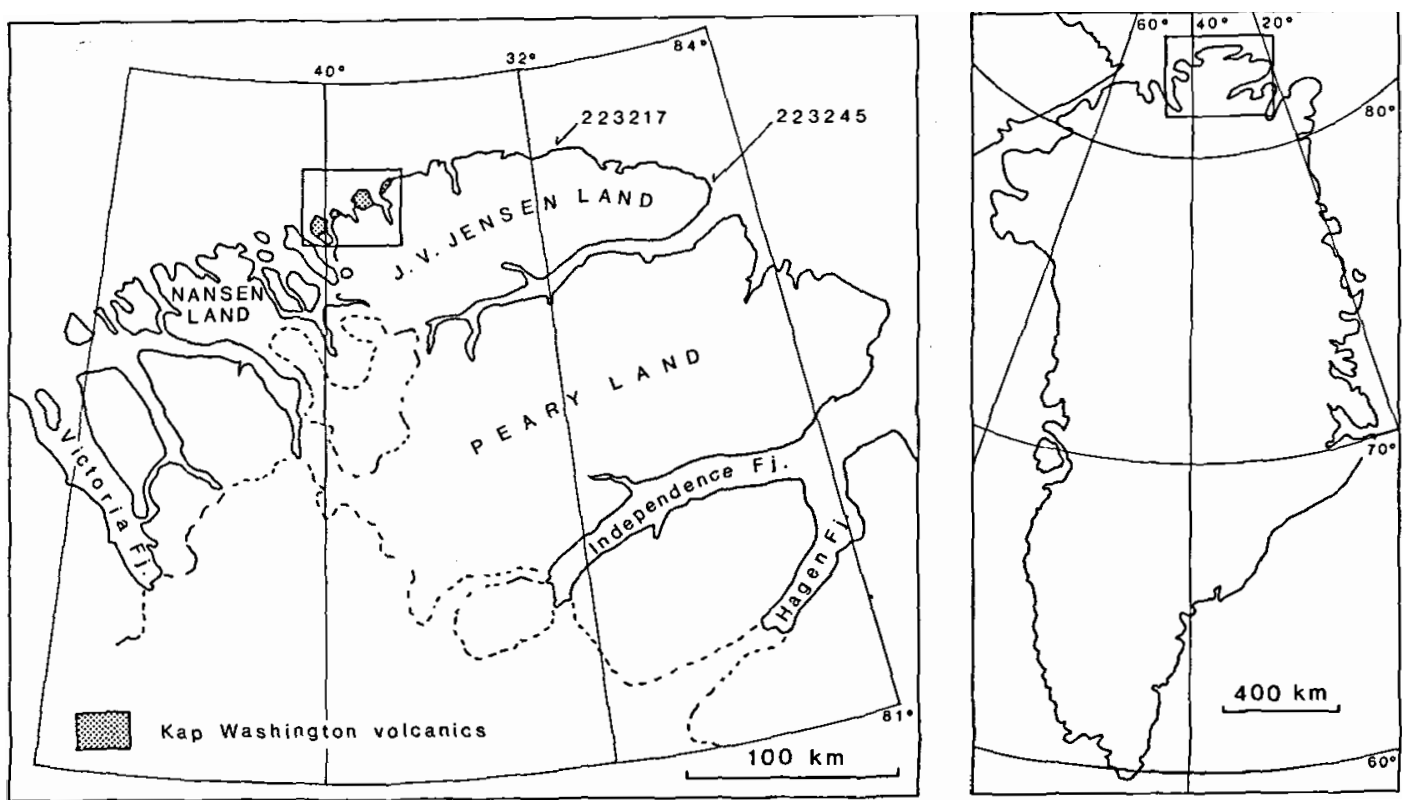

Fig. 1. Map of eastem North Greenland showing the location of the Kap Washington area and localities sampled for glacial erratics. Index map. 
Sample $22321730^{\circ} 40^{\prime} \mathrm{W} / 83^{\circ} 41^{\prime} \mathrm{N}$ Oodaaq $\varnothing$.

Brown polymict volcanoclastic rock full of subrounded clasts ranging in size up to 5 millimeters. These fragments vary from crystalline lava to fragments of pumice and vitric lava. Abundant are also crystal fragments of alkali feldspar, the original size of which must have been several millimeters. The feldspars display a variable perthite texture varying from microperthite to very coarse-grained feldspar intergrowths. Each feldspar grain may be composed of two or more twins (Carlsbad law?). Less common than feldspars are angular fragments of quartz. The matrix is mainly composed of deformed glassy shards, the shape of which strongly supports an ignimbritic origin for this rock.

The second sample was found on the coast of the mainland in eastern Johannes V. Jensen Land. This sample appears to be quite similar petrographically to the quartz-feldspar-phyric rhyolites exposed in the Kap Washington area, 120 kilometers further west.

Sample $22324525^{\circ} 42^{\prime} \mathrm{W} / 83^{\circ} 25^{\prime} \mathrm{N}$ Near I. P. Kochs Varde, Johannes V. Jensen Land.

Brown porphyritic lava. Millimeter-sized phenocrysts of quartz and perthitic alkali feldspars with penetrative twinning are set

in a fine-grained holocrystalline matrix. This matrix consists of quartz and feldspar garins up to 0.1 millimeter in size with reddish (hematite?) pigmentation along grain boundaries.

\section{Method}

$\mathrm{Rb} / \mathrm{Sr}$ ratios were determined by X-ray fluorescence analysis using a semi-manually operated Philips PW1410 spectrometer. The standard $\mathrm{GSP}-1(\mathrm{Rb} / \mathrm{Sr}=1.093)$ was used as reference standard. Errors in X-ray determination of $\mathrm{Rb} / \mathrm{Sr}$ ratios are estimated to be around \pm 1 percent. Isotopic errors are estimated to be around \pm 0.0007.

Table 1

Sample GGU no.

\begin{tabular}{lcl}
\hline 223217 & 7.36 & 0.7173 \\
223245 & 83.7 & 0.7764 \\
\hline
\end{tabular}

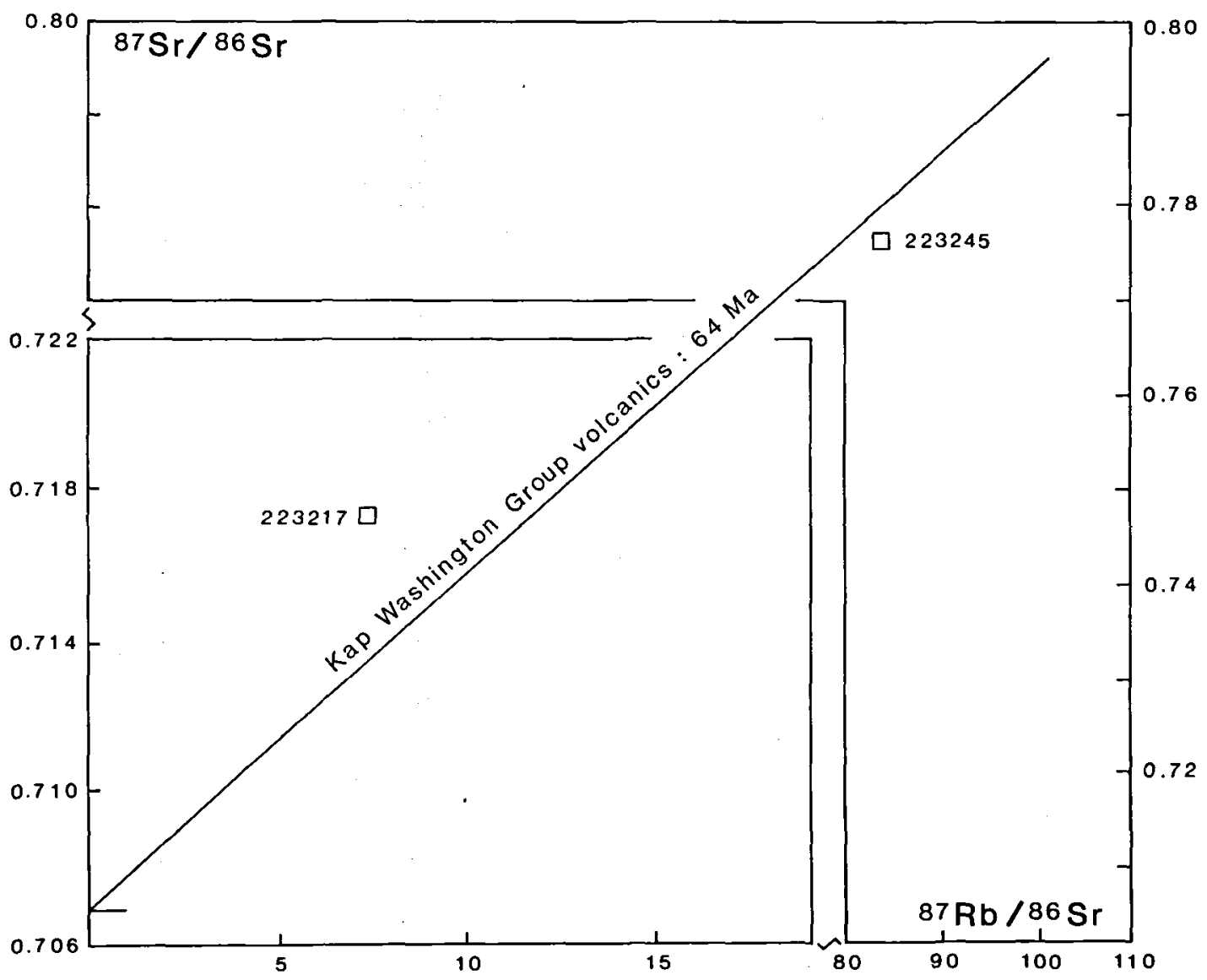

Fig. 2. Diagram showing Rb/Sr-isotopic data on glacial erratics in relation to the isochron obtained on volcanics from Kap Kane and kap Washington. 


\section{Results}

The results of the isotopic measurements are plotted in fig. 2 together with a reference line corresponding to the 64 million year isochron established on samples from the Kap Washington Group volcanics. Sample 223245 from I. P. Kochs Varde plots very close to this reference line. Sample 223245 from Oodaaq $\varnothing$ lies above the reference line and ages up to about 140 million years could be postulated for this erratic. However, if the initial isotopic ratio for $\mathrm{Sr}$ had been between 0.710 and 0.711 which is not far beyond the range recorded within the Kap Washington Group (0.707 to 0.709), then an age of 64 million years would be acceptable for the Oodaaq $\varnothing$ sample as well. If the two erratics selected for this study have a common source area, the isotopic data seem to favor the conclusion that this source area is related to the Kap Washington Group volcanics.

\section{Discussion}

Volcanic erratics occur abundantly on Kaffeklubben $\varnothing$ and on the small island Oodaaq $\varnothing$ to the north (fig. 3 ), while they are extremely rare on the adjacent coastal plain bordering the north coast of Greenland (Funder \& Hjort, 1980). This peculiar type of distribution appears also from a list of stone counts made by Davies (1961), showing 50 percent frequency of volcanic erratics on Kaffeklubben $\varnothing$, while this type of rock is absent from the sites on the nearby coastland. Apart from volcanic boulders the erratics encountered in this part of North Greenland are mainly low-grade metasediments that occur widespread in the mountains of the north Greenland fold belt (e.g. Davies, 1961; Koch, 1923 , p. 67 , Koch, 1928 , p. 517 ).

The petrographic and $\mathrm{Sr}$-isotopic characteristics of the volcanic erratics have established a firm relationship between these and the volcanic sequence cropping out at Kap Washington, and since no other occurrence of alkaline volcanic rocks is known from North Greenland these results support the contention that the erratics were indeed transported from the Kap Washington area, at a distance of ca. 80 kilometers from Kaffeklubben $\varnothing$.

The very few volcanic erratics found on the coastal plain were all associated with raised marine deposits, and may have been deposited from icebergs drifting along the coast as far as J. P. Kochs Varde, 120 kilometers to the south-east

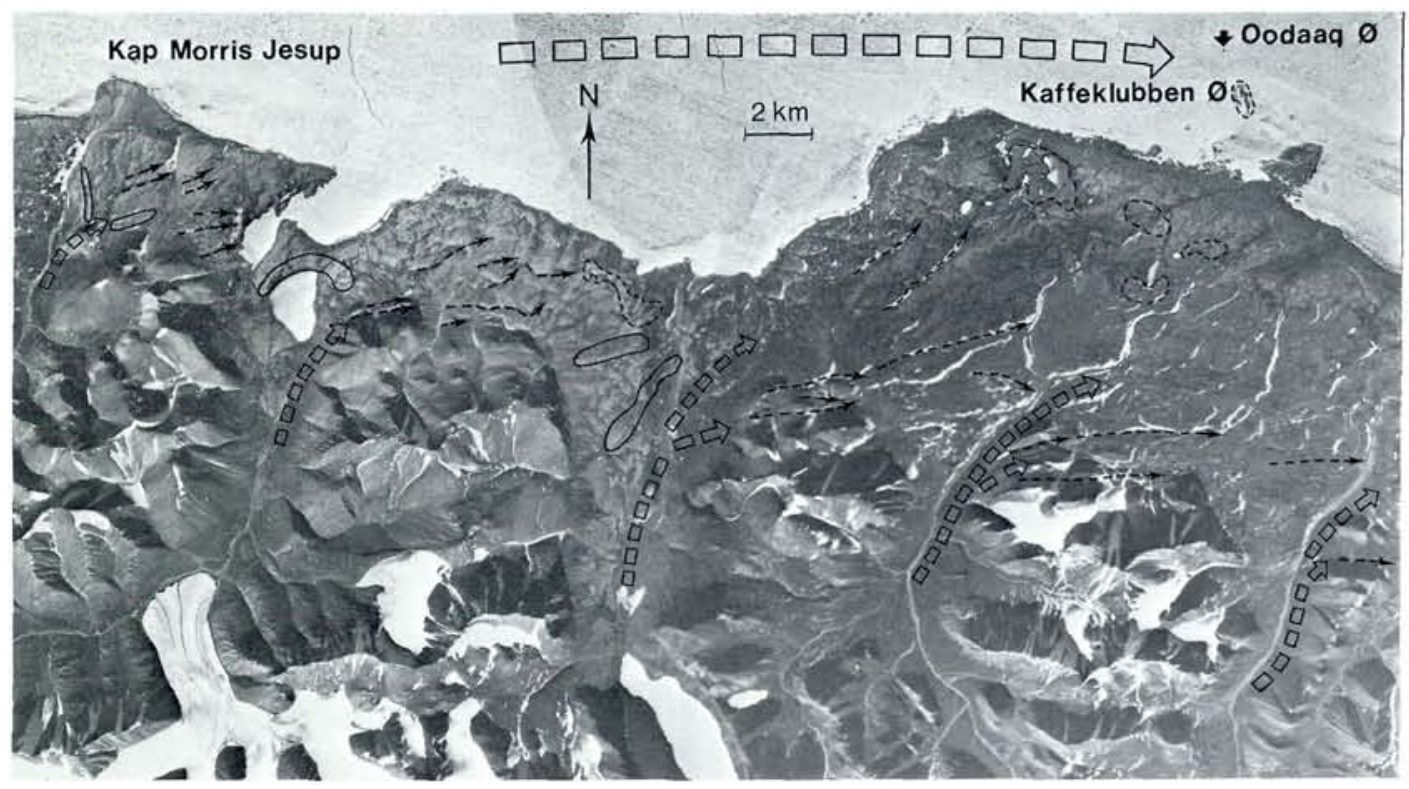

Fig. 3. Air photo mosaic showing an area at the north coast of Greenland. Broken lines: kames, full lines: moraines, broken arrows: glacial meltwater channels, open box arrows: flow lines for glaciers during the Weichselian.

(Reproduced with permission from the Geodetic Institute: A, 104/82 copywrite). 
of Kap Washington. However, this explanation does not satisfactorly account for their abundant occurrence on the two small islands off the coast, or for the variation in frequency between this area and the nearby coastland.

Kaffeklubben $\varnothing$, a 700 meter long and 30 meter high winding ridge, is the largest among a number of small islands in the area of shallow water that extends ca. 5 kilometers off the North Greenland coast. The tiny island Oodaaq $\varnothing, 50$ by 50 meters and 1 meter high, lies on the northern boundary of this area. In their surface both islands consist of littoral deposits and beach ridges, in which the erratic boulders occur. The area is apparently an abraded till deposit. By analogy with similar features on the adjacent coastal plain Kaffeklubben $\varnothing$ is interpreted as a kame, although this interpretation is contrary to that of Davies (1961) who thought it a lateral moraine. From these observations it appears that the erractic boulders on the two islands have been washed out from an underlying till deposit, implying that a glacier once moved along the North Greenland coast from Kap Washington towards the south-east. There is at least some additional evidence to support this conclusion. Observations on the nearby coastal plain show that the ice marginal features - moraines, kame terraces and glacial meltwater channels - all have a gradient towards south-east (fig. 3), showing that valley glaciers, on entering the coastal plain from valleys in the North Greenland mountain range, were deflected in this direction. It is difficult to imagine what caused this deflection, if it was not the presence of a large ice stream moving in this direction at some distance from the present coastline. The coastal plain, covered by local glaciers would receive glacially transported material only from nearby upland areas. This pattern of ice flow has been outlined in figure 3 .

C-14 dating of marine bivalve shells from raised deposits in the area has shown that isostatic uplift in the order of ca. 40 meters relative to present sea level, has taken place in Holocene times (Funder \& Hjort, 1980; Funder, 1982), and that the coastal plain was free of ice cover at least by 8500 years B. P. It appears from this evidence that the last ice cover in this area dates back to the Weichselian Ice Age.

Hence on the evidence of the erratic boulders and their demonstrated relation to the Kap
Washington volcanics, from the direction of ice marginal features on the coastal plain, and from C-14 dating of marine molluscs, it is postulated that an ice stream in Weichselian time moved along the north coast of Greenland, nourished by valley glaciers from the mountain range and, to some extent, by ice derived from the fjords in the Kap Washington area.

From observations made during his sledge journeys Koch $(1923$, p.68) concluded that during the maximum glaciation valley glaciers spread out to form a piedmont-glacier on the North Greenland coastal plain, while Davies (1961, p.103) speculated that ". .glaciation was of alpine type with valley glaciers extending onto and across the flat coastal plain.." to form a ". .piedmont glacier similar in form to the shelf ice on the north side of Ellesmere Island". The assumption of an ice stream moving along the coast indicates that the ice age glacial regime could have been slightly more vigorous than envisaged by these authors. The present theory, however, poses one major problem: Why would the ice masses, on entering the Arctic Ocean, choose this particular route?

Besides the volcanic erratics mentioned here, another perculiar occurrence of erratics on the north coast of Greenland was noted by Koch (1928, p.504) and Dawes (1970), comprising boulders of gneiss and granite found in till. Garnet-bearing gneisses are known to occur in the Kap Washington area south of the Kap Cannon Thrust, but granite has not been found in outcrop anywhere in this part of North Greenland, - and the reported occurrence of these erratics remains a mystery.

Acknowledgements. Christian Hjort, University of Lund, is acknowledged for his participation in the field work. The authors wish to thank the Geological Survey of Greenland for supporting their field work in Greenland and for permission to publish this report. They further acknowledge financial support from the Danish Natural Science Research Council and from the University of Copenhagen.

\section{Dansk sammendrag}

Glaciale blokke, fundet på Kaffeklubbens $\emptyset$ og Oodaaq $\emptyset$ samt på kysten endnu længere mod øst, er petrografisk meget lig vulkaniterne omkring Kap Washington. Sr-isotopsammensæetningen af to sådanne ledeblokke viser, at de aldersmæssigt tilhører Kap Washington vulkaniterne længere mod vest. Ud- 
bredelsen af disse ledeblokke støtter en række glacialmorfologiske observationer, der alle tyder på, at en isstrøm $\mathbf{i}$ Weichsel Istiden har bevæget sig østpå langs Grønlands nordkyst.

\section{References}

Davies, W. E. 1961: Glacial geology of northern Greenland. Polarforschung 5, 94-103.

Dawes, P. R. 1970: Quaternary studies in northern Peary Land. Rapp. Gronlands geol. Unders. 28, 15-16.
Funder, S. 1982: $\mathrm{C}^{14}$-Dating of samples collected during the 1979 expedition to North Greenland. Rapp. Grønlands geal. Unders. 110, 9-14.

Funder, S. \& Hjort, C. 1980: A reconnaissance of the Quaternary geology of eastern North Greenland. Rapp. Gronlands geol. Unders. 99, 99-105.

Koch, L. 1923: Resultaterne af Jubilæumsekspeditionen Nord om Grønland i 1921. Naturens Verden 7, 49-76. (In Danish).

Koch, L. 1928: The physiography of North Greenland. In: Vahl, $\mathrm{M}$ et al. (eds.): Greenland 1, 491-518. Copenhagen: C. A. Reitzel.

Larsen, O. 1982: The age of the Kap Washington Group volcanics, North Greenland. Bull. geol. Soc. Denmark, vol. 31, $\mathrm{xx}-\mathrm{xx}$. 